\title{
The Role of Substance P in Chronic Low Back Pain (CLBP)
}

\author{
Yusnita Rachmawati*1 and Hanik Badriyah Hidayati² \\ ${ }^{1}$ Master of Clinical Pharmacy Programme, Faculty of Pharmacy, Airlangga University, Surabaya, Indonesia \\ ${ }^{2}$ Department of Neurology, Faculty of Medicine, Airlangga University/Dr. Soetomo General Hospital, Surabaya, Indonesia \\ *E-mail: you_see_rose@yahoo.com
}

\begin{abstract}
Low Back Pain is one of the disease that causing global disability in the worldwide. In the past 10 years, prevalence of LBP has not decreased, it makes global burden increase substantially. Chronic low back pain(CLBP) is pain that is almost experienced daily by patients in the lower back region in a period of more than 3 months. Chronic low back pain is a mixture of pain that arises through nociceptive and neuropathic mechanisms. Over the past decade, numerous guidelines have been used in the management of CLBP. Problems that are still a controversy include the management of pain. The mechanism of many treatment measures is still in the low to moderate effectiveness stage, so that the pain management target is not optimal. Substance $\mathrm{P}$ is a neuropeptide that release both in acute and chronic pain. Therefore study about mechanisms that affect SP release may show important information regarding pathological alterations in pain perception
\end{abstract}

Keywords: chronic low back pain, substance P, nociceptive, neuropathic

\section{Introduction}

Low back pain (LBP) is the most common musculoskeletal condition causing more global disability affecting the adult population than another medical condition [1-3]. LBP cause disability that impact in productivity, require more research in the future than other musculoskeletal condition [4]. Economic burden showed by the high cost of healthcare spending directly and showed by decreased productivity indirectly. Social burden showed by restrict occupational activities [2,3]. The prevalence of LBP in adult estimeted up to $84 \%[1-3,5]$. In the past 10 years, prevalence of LBP has not decreased, it makes global burden increase substantially. Increasing life expectancy make people spend many years in old age, increasing rates of disability. The effective development in health care system needed to resolve the problem of this global burden $[1,4]$.

Low back pain (LBP) is a pain in the back region below the costal margin to the gluteal fold caused by several disorders related to the spine (spine) including intervertebratal discs, disc herniation, spinal stenosis and disc degeneration facet [1,3]. Examination by looking at various things including examinations of patients, radiological examinations and research with interventions show that intervertebratal discs have the largest percentage in the process of chronic low back pain which is around 39\% $-40 \%[2,6]$. Chronic low back pain (CLBP) is a pain that is almost experienced daily by patients in the lower back region in a period of more than 3 months [1-3]. Many literatures indicate that CLBP can be classified as mixed pain syndromes that can arise via nociceptive and neuropathic mechanism. [1,7,8].

Substance $\mathrm{P}$ has an leading role in pain mechanism by mediated central sensitization. The excitability of neurons spinal elevate after escalated afferen activity that implicate in nociception [9-11]. Substance $\mathrm{P}$ also has an pivotal role in the transition from acute to chronic pain and neurophatic pain mechanism. It involved nerve fiber that secrete substance P. Normally substance $\mathrm{P}$ excreted only by $\mathrm{C}$ fiber, but in chronic pain $A \beta$ fiber also may excrete substance $P[9,12-14]$. Hence, review about mechanisms that affect SP release may show important information regarding pathological alterations in pain perception [15]. This Review summarizes pain mechanism concepts in CLBP with central poin on the role of substance $\mathrm{P}$ in CLBP.

\section{Chronic Low Back Pain (CLBP)}

Chronic low back pain was described as pain lasting for a minimum of 12 weeks, occurring several times, in the back region from below costal margin to the gluteal line $[1,3,5]$. There are many factor affected in LBP such as depression, 
obesity, disuse, smoking status, chronic widespread pain and physical deconditioning.

Based on aetiologi and patient's clinical feature pain mechanism can be divided into nociceptive pain, inflammmation pain, and pahtological pain. Pathological pain can be devided into disfungsional and neuropathic pain $[1,16]$. Many literatures prove evidences that CLBP can be classified as mixed pain syndromes that can arise via nociceptive and neuropathic mechanism. $[1,7,8]$. Nociceptive pain, is physiological defensive pain implicate activation of nociceptor neuron. Nociceptor neuron that implicate mainly high-threshold nociceptor neurons, and activated by noxious stimuli. Neuropathic pain involving nerve maladaptive plasticity that caused by a disease or lession. It affects the somatosensory system and revise nociceptive signal processing and made enhance responses to stimuli and cause allodynia $[1,8,17,18]$.

In CLBP, neuropathic pain caused by mechanical compression of the nerve root from a lesions of nerve fibres sprouts within a degenerated disc (local neuropathic pain), herniated intervertebral disc (mechanical neuropathic root pain), and the action on nerve fibres of inflammatory mediators arising from a degenerated disc (inflammatory neuropathic root pain) $[1,8]$. Many cytokin and neuropeptida such as nerve growth factor and substance $\mathrm{P}$ seem to have important part in these processes and make future clinical research focus on the biological therapies $[1,19]$.

Nociception is the process when stimuli can be recognize by a peripheral nerve fibers, called nociceptors. There are three type of stimuli: chemical, mechanical, or thermal stimuli. Nociceptive nerve fiber can be in the myelinated or unmyelinated form. There are two major classes of nociceptors, A $\delta$ fiber and C-fiber [20-22]. Noxious stimuli that include thermal, chemichal and mechanical stimuli, are sensed by peripheral nociceptive neurons that are classified as $\mathrm{C}$-fiber or $\mathrm{A} \delta$-fiber. A third type $\mathrm{A} \beta$ fibers, are imply in the conduction of non-nociceptive inputs (movement, light touch or vibration under normal physiological conditions) $[23,24]$. A $\delta$ fiber mediate acute or fast pain and because of a medium diameter myelinated.. The second nociceptor class are C-fiber that includes small diameter unmyelinated that mediates , "second" or slow pain [21]. A $\delta$ fiber are myelinated, have a relatively fast conduction and cause primary pain, wheras $\mathrm{C}$ fiber are unmyelinated, have a relatively slow conduction and cause secondary pain. C-fibers nociceptors actuated by mechanical, thermal and chemical stimuli, thus called polymodal. Based on neurochemistry, C-fibers can be categorizes as either peptidergic or non-peptidergic. Peptidergic C-fibers releases neuropeptides, calcitonin generelated peptide (CGRP), neurokinins and substance $\mathrm{P}$ (SP). Peptidergic C-fibers also express the TrkA neurotrophin receptor, which responds to nerve growth factor (NGF). The nonpeptidergic $\mathrm{C}$-fiber expresses the c-Ret neurotrophin receptor that is targeted by glial-derived neurotrophic factor (GDNF), as well as neurturin and artemin [21,25,26].

Normally $A \beta$ fiber may not excrete substance $P$, but if there are inflammation in nerve fiber, $A \beta$ fiber may secrete substance $\mathrm{P}$ in dorsal horn. [9,12-14]. The sense of pain is related with the receptors respon in the primary afferent fibers, which is include of the peripheral nociceptive neurons. Both nociceptors remain inactive during homeostasis and are activated when there is a potential of noxious stimulus $[23,24,27]$.

In chronic low back pain patients, body position or daily work which causes excessive low back movement and other mechanical causes will cause excessive stimulation of the lower back muscles. Excessive stimulation of the lower back muscles will then lead potential injury to the tendons, muscle fibers and ligaments $[1,2,28]$. Injury in tendons muscle fibers, or ligaments will release inflammatory mediators. Macrophages will produce nerve growth factor (NGF) which will bind to the receptor, TrkA. This bonding will activate the PKC and affect the ligand gate channel TRPV1. TRPV1 increase $\mathrm{Ca}^{2+}$ and also influence the release of substance $\mathrm{P}$ in the afferent terminal of the $\mathrm{C}$ fibers. TRPV1 also raises an action potential that will cause peripheral sensitization, which if continued continues there will be central sensitization in the posterior horn spinal cord. Chronic low back pain is a mixture of pain that arises through nociceptive or neuropathic mechanisms [9,26,29,30].

Over the past decade, numerous guidelines have been published on the assessment and management of CLBP. Most of these guidelines based on recent evidence clinical practice are made by general approval and recommend physical activity and pharmacotherapy combined with multidisciplinary, psychosocial and behavioural approaches. A guidelines should approve the best care to patient respectively and to decrease the number of patient CLBP with disability so the effect in economic and social society can be evaded. The main goal of treatment in chronic low back pain is managemen in pain to reduce pain and maintain function. Treatment on the guideline may prevent future exacerbation, so it is important to standardize the practices and make an care pathway for the management of low back pain [31-33].

Most of the guidelines give guidance a multimodal approach to the management of chronic LBP, used both pharmacological and nonpharmacological therapies. Non pharmacological therapies such as physical activity and physioterapi, also have an important role in therapies approaches. Treatment's choice should be individualized in patients according to the patient's needed and severity of symptoms, potential adverse effect and drug interaction,comorbid factor, and also cost of effectiveness $[18,31,34]$.

The effect therapy of many treatments in the guidelines remain unclear, most treatments are low to moderate and final 
goal therapy to reduce pain is infrequently achievable $[1,35,36]$. Therefore, the aim of pain management is to decreasing dysfunction and increasing quality of life for patients by achieve relief in pain and minimizing adverse effects. Most guidelines, recommend the use of paracetamol, NSAIDs and weak opioids. In spite of the publication of many guidelines, current therapy design are consistent with overuse of some drug and therapy, and underuse of exercise [1,37].

Paracetamol is recommended in almost guidelines as first line therapy in low back pain both acute and chronic. Many systematic review is sort of information to reinforece its use in chronic low back pain. In the Treatment of CLBP parasetamol is less effective than NSAID, but parasetamol still use widely because of minimalize adverse effect, and patients that contraindication in using NSAID (such as patiens with kidney disease) [1,38].

Research on paracetamol and $\mathrm{P}$ substance itself has been conducted, where the analgesic effect of paracetamol is related to the inhibition of NO pathways involving the substance $\mathrm{P}$ and NMDA, resulting in a blockade of spinal hyperalgesia [39-43].

Paracetamol has analgesic and antipyretic effect similar to NSAIDs, but contrary to NSAIDs, paracetamol has no antiinflammatory activity. When used at the recommended dosage, paracetamol does not cause gastrointestinal side effects such as NSAIDs. However, paracetamol works also by suppressing prostaglandin production $[43,44]$.

The concept that refers to the mechanism of action of COXdependent central paracetamol shows that paracetamol actually inhibits prostaglandin synthesis in well-functioning cells, but does not have the same effect on tissue / cell homogenates, where arachidonic acid concentrations are low. Second, paracetamol mechanism of action by inhibit COX -1 and COX-2 activity in peripheral tissues.but have a stronger impact to COX-2, especially in blood vessel endothelial cells $[42,44]$.

The enzymes that play a role in the metabolism of arachidonic acid to prostanoids (consist of prostaglandins and thromboxanes), are cyclooxygenases, or more accurately named prostaglandin $\mathrm{H}_{2}$ synthetase (PGHS), and have two active sides, COX and peroxidase (POX). The transformation from arachidonic acid to actual prostanoid through a two-stage process, first requires activation from the $\mathrm{COX}$ side to produce unstable intermediate hydroperoxide, prostaglandin $\mathrm{G}_{2}$ $\left(\mathrm{PGG}_{2}\right)$, which is then converted to prostaglandin $\mathrm{H}_{2}\left(\mathrm{PGH}_{2}\right)$ through POX. The enzymatic activity of COX depends on its presence in an oxidized form where paracetamol interferes indirectly by reducing the co-substrate at the POX site. In intact cells, when arachidonic acid levels are low, paracetamol is a potential inhibitor of PG synthesis by blocking physiological regeneration of POX. But in damaged cells, where the concentration of hydroperoxide is high, prostaglandin synthesis alone is weakly inhibited. This COX- dependent peroxide mechanism explains the different activity of paracetamol in the brain when the peroxide concentration is low and the inflammatory side is peripheral with high peroxide content [1,42-44].

Another mechanism for paracetamol is activation of the serotoninergic pathway. The serotonergic pathway is part of the pain system of the descending pathway, originating in the core of the brain stem, hypothalamus, and cortex, and interacting with afferent pain nerves in the dorsal horn. Serotonin receptors exist along the central nervous system, which are implicated in a number of functions, including awareness, mood, memory, and nausea and vomiting, the latter being mediated through the 5-HT3 subtype receptors. The mechanism of action of paracetamol that activation of the descending serotonergic pathway plays a pivotal role and it has been shown that the antinociceptive effect of paracetamol can be partially inhibited by co-administration of the 5-HT3 receptor antagonist (tropicetron or granisetron). This becomes interesting using anti-emetic drugs which are often given together with paracetamol in the perioperative period [4244].

Inhibition of formation of nitrogen oxides (NO) may also be an alternative analgesic mechanism of paracetamol. The Larginine / NO pathway is activated by substance $\mathrm{P}$ and NMDA receptors to trigger NO synthesis, which is an pivotal neurotransmitter in the nociceptive process of the spinal cord [42-44].

The role of NO in the peripheral nociceptive process is more complex and is reported to include both nociceptive and non-nociceptive. These results depend on studies in experimental animal models with the application of nociceptive stimuli [45]. The hypothesis regarding the mechanism of action of paracetamol which shows a central potential mechanism is inhibition through the inhibition of Larginine NO nociceptive pathway. In this study, mice were divided into 3 treatment groups, namely AMPA, NMDA and substance $\mathrm{P}$ groups. The control and treatment groups with paracetamol were both given L and D arginine injections. Then the AMPA control group was given AMPA injection only, while the AMPA treatment group was given AMPA injection followed by administration of paracetamol. Likewise with the NMDA group and substance P. The results showed that there was a significant decrease in the substance group $\mathrm{P}$ and NMDA, but not in the AMPA group. Research shows that the antinociceptive effect is influenced by the natural Larginine substrate but is not influenced by $\mathrm{D}$-arginine, so the analgesic effect of paracetamol is associated with inhibition of NO formation in the L-arginine-NO pathway. The potential mechanism of paracetamol involves NMDA and substance P through the NO pain pathway [40]. 


\section{Substance $P$}

Substance P -a highly conserved peptide- discovered in 1931 by von Euler and Gaddum. They reported that extracts of equine brain and gut extract-distinct from acetylcholinecontained a hypotensive and spasmogenic factor [46-48]. It was initially named as "preparation P" because this substance was purified and dried in powder form. The activity of this hypotensive and spasmogenic factor resided in the watersoluble powdered extracts of the brain and intestinal tissue. The preparation $P$ then later was named "Substance P." [4749]. Substance $P$, was later found to be proteinaceous and highly conserved homologs identified in mice, rabbits and human $[47,48,50]$. In the early 1970-1971, Leeman's group determined the amino acid composition of SP from the isolation from bovine hypothalamic tissue. The structure of SP is consist of eleven amino acid (Arg-Pro-Lys-Pro-Gln-GlnPhe-Phe-Gly-Leu-Met-NH2) and has a net positive charge under physiological $\mathrm{pH}$ [47-49].

$\mathrm{SP}$ is a part of the tachykinin (TAC) family of neuropeptides and is encoded by the TAC1 gene [47,48,51]. There are the three main tachykinins in mammals: Substance $\mathrm{P}$, neurokinin A (NKA) and neurokinin B (NKB). Tachykinin family members are distributed in all mammalian tissues and body fluids, but the highest densities of SP are founded in the nervous system both in CNS and the peripheral nervous system $[11,48,52,53]$. Three area that have the highest densities of SP are in the dorsal horn of the spinal cord, the substantia nigra and the amygdala [11,53]. All Tachykinin family members interact and mediated with all the threereceptor subtypes. There are at least three specific receptors, the neurokinin-1 receptor (NK-1R), NK-2R, and NK-3R. The affinity of these neurokinin receptors in binding to substance $P$ is in the order of NK1R $>$ NK2R $>$ NK3R. Substance $P$ preferring NK1R, NKA preferring NK2R and NKB preferring NK3R [11,54]. Substance P is synthesized in the ribosome as a larger protein and then enzymatically converted into the active undecapeptide [55]. Substance P in neuron is expressed in the soma. After SP was synthesized, SP is transported in large dense-core vesicles (LDCVs) and the peptide is released through the exocytosis of LDCVs either at axonal terminals or at the neuronal soma $[11,48,56]$. After exocytosed, SP binds to membrane-bound. Substance $P$ receptor expressed either on the same cell or on the neighboring cells. A cell surface metalloendopeptidase named neprilysin degrade unbound SP, and thereby suggests a shorter half-life of SP in tissues $[48,57]$.

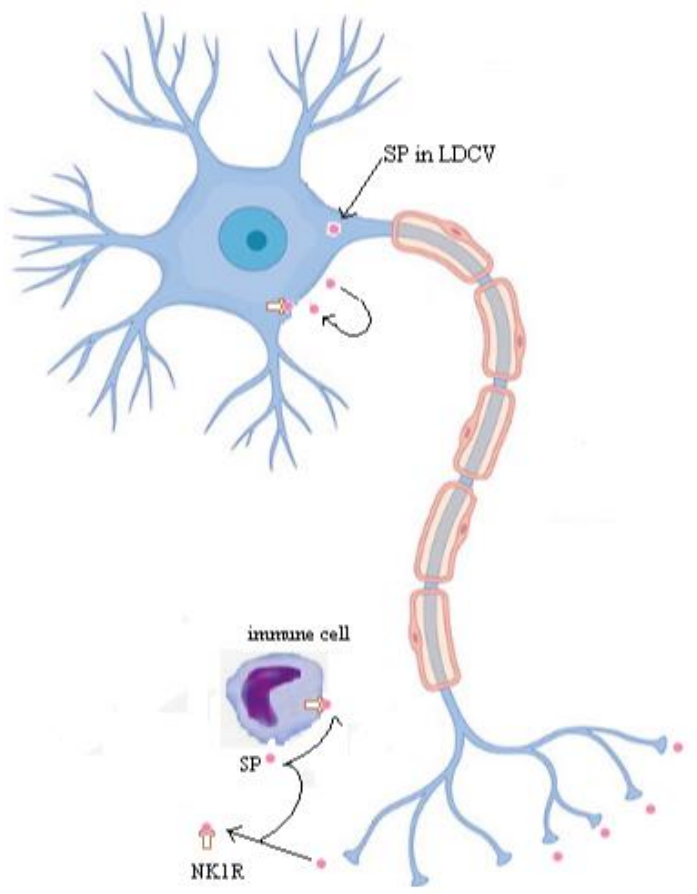

Figure 1. Substance P production by a neuronal cell and an immune cell type [48]

SP binding to NK1R mediates rapid endocytosis and internalization of the receptor; this also contributes to desensitization of cells to SP signaling. Interaction between substance $\mathrm{P}$ and NK1 receptors signals to several intracellular pathways. These pathways involve second messengers, such as diacyl-glycerol (DAG), inositol trisphosphate (IP3), and 
cyclic adenosine monophosphate (cAMP) [47,58]. Substance $\mathrm{P}$ binding to NK1R also activates phospholipase $\mathrm{C}$, which catalyzes the hydrolysis of phosphoinositides into inositol 1,4,5-trisphosphate and diacylglycerol. Inositol triphosphate are then available for the mobilization of calcium from internal reticular stores, and increases the level of of cytosolic $\mathrm{Ca}^{+}$, and diacylglycerol activates protein kinase C. NK1R signaling can also activate adenylyl cyclase. It causes the generation of cAMP, and the latter activates protein kinase A $[47,48]$.

\section{Challenges and oportunities of Substance $P$}

The transition from acute to chronic pain states might be the most important challenge to maximize pain management in chronic low back pain. Substance P plays a pivotal role in this transition, thus studying mechanism that effect SP secretion can provide important information concerning alterations in the pain perception.

The recent finding that CBP has a neuropathic pain component, change pharmacological strategies. A systematic review evaluate the efficacy of pharmacological monotherapy and combination therapy in CLBP, with specific reference to the management of nociceptive and neuropathic pain components [1]. Whereas NSAIDs, paracetamol and COX-2 inhibitors target only the nociceptive component of CLBP, opioids target both nociceptive and neuropathic pain, and antidepressants target only the neuropathic componen. It made patients with CLBP require combination therapy in order to manage both the nociceptive and neuropathic pain components.

\section{Summary}

The important role of substance $\mathrm{P}$ secretion from nerve fiber in acute and chronic low back pain which substance $\mathrm{P}$ participates suggests a major future role for neurokinin receptor antagonists in the management of these diseases. More studies with neurokinin receptor antagonists that blocking the binding of SP to the NK-1R, drug that effect release of substance $\mathrm{P}$, or drug that reduce substance level needed to be research to reduce pain in chronic low back pain.

\section{References}

[1] Morlion B. Chronic low back pain: pharmacological, interventional and surgical strategies. Nat Rev Neurol 2013;9(8):462-73.

[2] Allegri M, Montella S, Salici F, Valente A, Marchesini M, Compagnone $\mathrm{C}$, et al. Mechanisms of low back pain: a guide for diagnosis and therapy. F1000Research. 2016;5:1530.

[3] Khan AN, Jacobsen HE, Khan J, Filippi CG, Levine M, Lehman RA, et al. Inflammatory biomarkers of low back pain and disc degeneration: a review. Ann $\mathrm{N}$ Y Acad Sci. 2017;1410(1):68-84.
[4] Hoy D, March L, Woolf A, Blyth F, Brooks P, Smith E, et al. The global burden of neck pain: estimates from the global burden of disease 2010 study. Ann Rheum Dis. 2014;73(7):1309-15.

[5] Almeida DC, Kraychete DC. Low back pain - a diagnostic approach. Rev Dor. 2017;18(2):173-7.

[6] Freemont AJ. The cellular pathobiology of the degenerate intervertebral disc and discogenic back pain. Rheumatology. 2009;48(1):5-10.

[7] Freynhagen R, Baron R, Tölle T, Stemmler E, Gockel U, Stevens M, et al. Screening of neuropathic pain components in patients with chronic back pain associated with nerve root compression: a prospective observational pilot study (MIPORT). Curr Med Res Opin. 2006;22(3):529-37.

[8] Freynhagen R, Baron R. The evaluation of neuropathic components in low back pain. Curr Pain Headache Rep. 2009;13(3):185-90.

[9] Lin Q, Li D, Xu X, Zou X, Fang L. Roles of TRPV1 and neuropeptidergic receptors in dorsal root reflex-mediated neurogenic inflammation induced by intradermal injection of capsaicin. Mol Pain. 2007;3.

[10] Ji RR, Xu Z, Gao Y. Emerging targets in neuroinflammationdriven chronic pain. Nat Publ Gr. 2014;13(7):533-48.

[11] Zieglgänsberger W. Substance $P$ and pain chronicity. Cell Tissue Res. 2019;375(1):227-41.

[12] Meliala, L; Suryamiharja, A; Purba, J; Sadeli H. Patofisiologi nyeri punggung bawah. In: Nyeri punggung bawah. PERDOSSI; 2003. p. 17-28.

[13] Li D, Ren Y, Xu X, Zou X, Fang L, Lin Q. Calcitonin Generelated Peptide Driven by Dorsal Root Reflexes. J Pain. 2008;9(12):1155-68.

[14] Bannister K, Kucharczyk M, Dickenson AH. Hopes for the future of pain control. Pain Ther. 2017;6(2):117-28.

[15] Marvizón JCG. Substance P release in the dorsal horn assessed by receptor internalization: NMDA receptors counteract a tonic inhibition by GABA B receptors. Eur $\mathrm{J}$ Neurosci. 1999;11(2):417-26.

[16] Wong AY, Karppinen J, Samartzis D. Low back pain in older adults: risk factors, management options and future directions. Scoliosis Spinal Disord. 2017;12(1):1-23.

[17] Dworkin RH, O'Connor AB, Audette J, Baron R, Gourlay GK, Haanpää ML, et al. Recommendations for the pharmacological management of neuropathic pain: an overview and literature update. Mayo Clin Proc. 2010;85(3 SUPPL.).

[18] Baron R, Binder A, Attal N, Casale R, Dickenson AH, Treede RD. Neuropathic low back pain in clinical practice. Eur J Pain (United Kingdom). 2016;20(6):861-73.

[19] Wang H, Woolf CJ. Pain TRPs. Neuron. 2005;46(1):9-12.

[20] Meyer RA, Ringkap M, Campbell JN, Raja SN. Peripheral mechanisms of cutaneous nociception. In: McMahon SB, Koltzenburg M, editors. Wall and Melzack's Textbook of Pain. Philadelphia: Elsevier; 2008. p. 3-34.

[21] Basbaum AI, Bautista DM, Scherrer G, Julius D. Cellular and molecular mechanisms of pain. Cell. 2009;139(2):267-84.

[22] Honoré P, Menning PM, Rogers SD, Nichols ML, Basbaum AI, Besson J-M, et al. Spinal Substance P Receptor Expression and Internalization in Acute, Short-Term, and Long-Term Inflammatory Pain States. J Neurosci. 2018;19(17):7670-8. 
[23] Gangadharan V, Kuner R. Pain hypersensitivity mechanisms at a glance. Dis Model Mech. 2013;6(4):889-95.

[24] Yam MF, Loh YC, Tan CS, Adam SK, Manan NA, Basir R. General pathways of pain sensation and the major neurotransmitters involved in pain regulation. Int $\mathbf{J}$ Mol Sci. 2018;19(8).

[25] Dong X, Han S kyou, Zylka MJ, Simon MI, Anderson DJ. A diverse family of GPCRs expressed in specific subsets of nociceptive sensory neurons. Cell. 2001;106(5):619-32.

[26] Rogoz K, Andersen HH, Kullander K, Lagerstrom MC. Glutamate, substance $\mathrm{P}$, and calcitonin gene-related peptide cooperate in inflammation-induced heat hyperalgesia. Mol Pharmacol. 2013;85(2):322-34.

[27] Sahbaie P, Shi X, Guo TZ, Qiao Y, Yeomans DC, Kingery WS, et al. Role of substance $\mathrm{P}$ signaling in enhanced nociceptive sensitization and local cytokine production after incision. Pain. 2009;145(3):341-9.

[28] Fishbain DA, Cole B, Lewis JE, Gao J. What is the evidence that neuropathic pain is present in chronic low back pain and soft tissue syndromes? An evidence-based structured review. Pain Med (United States). 2014;15(1):4-15.

[29] Sossin WS. Isoform specificity of protein kinase Cs in synaptic plasticity. Learn Mem. 2007;14(4):236-46.

[30] Reichling DB, Levine JD. Critical role of nociceptor plasticity in chronic pain. Trends Neurosci. 2009;32(12):611-8.

[31] Koes BW, Van Tulder M, Lin CWC, Macedo LG, McAuley J, Maher C. An updated overview of clinical guidelines for the management of non-specific low back pain in primary care. Eur Spine J. 2010;19(12):2075-94.

[32] Buchbinder R, van Tulder M, Öberg B, Costa LM, Woolf A, Schoene M, et al. Low back pain: a call for action. Lancet. 2018;391(10137):2384-8

[33] Oliveira CB, Maher CG, Pinto RZ, Traeger AC, Lin CWC, Chenot JF, et al. Clinical practice guidelines for the management of non-specific low back pain in primary care: an updated overview. Eur Spine J. 2018;27(11):2791-803.

[34] Laplante BL, Ketchum JM, Saullo TR, Depalma MJ. Multivariable Analysis of the Relationship between Pain Referral Patterns and the Source of Chronic Low Back Pain. Pain Physician. 2012;15(2):171-8.

[35] Keller A, Hayden J, Bombardier C, Van Tulder M. Effect sizes of non-surgical treatments of non-specific low-back pain. Eur Spine J. 2007;16(11):1776-88.

[36] Mannion AF, Balagué F, Pellisé F, Cedraschi C. Pain measurement in patients with low back pain. Nat Clin Pract Rheumatol. 2007;3(11):610-8.

[37] Carey TS, Freburger JK, Holmes GM, Castel L, Darter J, Agans R, et al. A long way to go: Practice patterns and evidence in chronic low back pain care. Spine (Phila Pa 1976). 2009;34(7):718-24.

[38] Van Tulder M, Becker A, Bekkering T, Breen A, Del Real MTG, Hutchinson A, et al. Chapter 3: european guidelines for the management of acute nonspecific low back pain in primary care. Eur Spine J. 2006;15(SUPPL. 2):169-91.

[39] Hunskaar S, Fasmer OB, Hole K. Acetylsalicylic acid, paracetamol and morphine inhibit behavioral responses to intrathecally administered substance P or capsaicin. Life Sci. 1985;37(19):1835-41.

[40] Björkman R, Hallman KM, Hedner J, Hedner T, Henning M. Acetaminophen blocks spinal hyperalgesia induced by NMDA and substance P. Pain. 1994;57(3):259-64.

[41] Bujalska M. Effect of nitric oxide synthase inhibition on antinociceptive action of different doses of acetaminophen. Pol J Pharmacol. 2004;56(5):605-10.

[42] Anderson BJ. Paracetamol (acetaminophen): mechanisms of action. Paediatr Anaesth. 2008;18(10):915-21.

[43] Jozwiak-Bebenista M, Nowak JZ. Paracetamol: mechanism of action, applications and safety concern. Acta Pol Pharm - Drug Res. 2014;71(1):11-23.

[44] Sharma C V., Mehta V. Paracetamol: mechanisms and updates. Contin Educ Anaesthesia, Crit Care Pain. 2014;14(4):153-8.

[45] Janicki PK, Jeske-Janicka M. Relevance of nitric oxide in pain mechanisms and pain management. Curr Rev Pain. 2007;2(4):211-6.

[46] Van Euler Us, Gaddum J. An unidentified depressor substancein certain tissue extracts. J Physiol 7274-87). 1931;72:74-87.

[47] Mashaghi A, Marmalidou A, Tehrani M, Grace PM, Pothoulakis C, Dana R. Neuropeptide substance P and the immune response. Cell Mol Life Sci. 2016;73(22):4249-64.

[48] Suvas S. Role of substance P neuropeptide in inflammation, wound healing, and tissue homeostasis. J Immunol. 2017;199(5):1543-52.

[49] Chang M, Leeman S. Isolation of a sialogogic peptide from bovine hypothalamic tissue and its characterization as substance P. J Biol Chem. 1970;245(18):4784-90.

[50] Severini C, Improta G, Falconieri-Erspamer G, Salvadori S, Erspamer V. The tachykinin peptide family . Pharmacol Rev. 2002;54(2):285-322.

[51] Pennefather JN, Lecci A, Candenas ML, Patak E, Pinto FM, Alberto C. Tachykinins and tachykinin receptors : a growing family. Life Sci. 2004;74(12):1445-63.

[52] Hokfelt T, Vincent S, Dalsgaard C., Skirboll L, Johansson O, Schultzberg M, et al. Distribution of substance $\mathrm{P}$ in brain and periphery and its possible role as a co-transmitter . Ciba Found Symp. 1982;91:84-106.

[53] Ribeiro-da-silva A, Hökfelt T. Neuroanatomical localisation of substance $\mathrm{P}$ in the CNS and sensory. Neuropeptides. 2000;34(5):256-71.

[54] Ganjiwale A, Cowsik S. Molecular recognition of tachykinin receptor selective agonists : insights from structural studies . Mini Rev Med Chem. 2013;13(14):2036-46.

[55] Maggi CA. The troubled story of tachykinins and neurokinins. TiPS. 2000;21(May):173-5.

[56] Camilli P De, Jahn R. Pathways to regulated exocytosis in neurons. Annu Rev Physiol. 1990;52:625-45.

[57] Skidgel RA, Engelbrecht S, Johnson AR, Erdos EG. Hydrolysis of Substance P and Neurotensin by Converting Enzyme and Neutral Endopeptidase. Peptides. 1984;5:769-76.

[58] Douglas SD, Leeman SE. Neurokinin-1 receptor: Functional significance in the immune system in reference to selected infections and inflammation. Ann $N$ Y Acad Sci. 2011;1217(1):83-95. 